\title{
円環状に配列したビームからのベッセルビームの発生
}

\author{
佐伯 拓 $^{1}$, 橋本 和久 $^{2}$, 本越 伸二 $^{1}$, 今崎 一夫 ${ }^{1}$, 藤田 尚徳 ${ }^{2}$, \\ 中塚 正大 ${ }^{1,2}$, 山中 千代衛 ${ }^{1}$ \\ 1 (財) レーザー技術総合研究所 ( $=550-0004$ 大阪市西区勒本町1-8-4) \\ 2大阪大学レーザーエネルギー学研究センター（５65-0871 大阪府吹田市山田丘2-6）
}

\section{Generation of a Bessel Beam from Annularly Arranged Multi-Beams}

\author{
Taku SAIKI, ${ }^{1}$ Kazuhisa HASHIMOTO,${ }^{2}$ Shinji MOTOKOSHI, ${ }^{1}$ Kazuo IMASAKI, ${ }^{1}$ \\ Hisanori FUJITA, ${ }^{2}$ Masahiro NAKATSUKA,,${ }^{1,2}$ and Chiyoe YAMANAKA ${ }^{1}$ \\ ${ }^{1}$ Institute for Laser Technology, 1-8-4 Utsubo-honmachi, Osaka 550-0004 \\ ${ }^{2}$ Institute of Laser Engineering,Osaka University, 2-6 Yamada-oka, Suita, Osaka 565-0871
}

(Received April 11, 2008)

\begin{abstract}
A laser beam passes through 12 or 24 circular apertures arranged annularly, and the transmitted beams overlapped with each other in phase to generate a Bessel beam. The resultant beam propagates and maintains characteristic narrow energy distribution that agrees with the results of numerical calculation.
\end{abstract}

Key Words: Bessel beam, Solid-state laser, Phase matching

1.はじめに

近年，レーザー技術の急速な進歩によりレーザーを用 いたエネルギーの伝送に関する研究が行われている．固 体, ファイバレーザーでの大出力パワーレーザーが現実 のものとなり, 大出力エネルギー伝送が可能となっ た1,2). 今現在，Ybファイバレーザーの効率は連続波で 80 $\%$, 電源効率は $35 \%$ に達して抢り, $20 \mathrm{~kW}$ のルチモード 出力のレーザーがIPGフォトニクスで達成されている2).

一方, 自然環境の保護や有効利用への関心が高まりを 見せている，宇宙空間での太陽光自然エネルギーの有効 利用のため, 宇宙太陽光発電システムの実現に向けて, 日本や米国, ドイッ, イスラエルで関連した研究が精力 的に進められている. 宇宙太陽光発電システムとは静止 軌道上に衛星を打ち上げ，この衛星で捕集した太陽光エ ネルギーを地上に伝送するシステムである。地上へのエ ネルギー伝送媒体としてマイクロ波を用いた方式とレー ザー光を用いた方式が提案されている。レーザー方式で は太陽光を励起源としてレーザーを発振させる太陽光励 起レーザーが開発されており, 太陽光からレーザー光へ 高効率の変換が可能となってきた ${ }^{3)}$.

現在，このように小型・高出力レーザーの開発が進 み, 指向性ビームエネルギー伝送の実用化の可能性が高 まりつつある。一方，レーザー，マイクロ波等によるエ ネルギー伝送に関する研究も平行して行われている。 レーザーとマイクロ波方式を比較した場合, ともに電磁 波であるが，レーザーは周波数が高く回折広がりが小さ
い.このため高エネルギー密度で伝送可能，受光側の装 置を小さくできるという利点がある。レーザーエネル ギー伝送の応用例として, 人工衛星間や移動体への工ネ ルギー供給, ソーラーセイル, レーザー推進等, 宇宙地 上間でのエネルギー伝送が挙げられる。すでにレーザー 光でエネルギー伝送を行い，これを電力に変換してロ ボットやヘリコプター等を駆動する研究が近畿大学河島研 究所等で行われている4). また，ビーム伝送の要素技術と して, 発振器, 伝送(地上では大気擾乱の影響大), 受光側 の光電変換, ビームポインティング制御も重要である3). 実用的な機械を動かすためには，kWクラスのレーザーパ ワー伝送が必要である。しかし, 単一ビームでのエネル ギー発生量には限界がある。ファイバレーザーでは光学 ダメージや非線形効果によるレーザー出力の制限, 固体 レーザーでは主に熱レンズ効果によりレーザー出力が制 限される.1本のレーザービームでMW近い高出力パワー を得るというのは困難であると考えられる

ガウスビームは長距離伝播すると回折によりビームの 幅が無限に広がり強度が弱まる。長距離伝播するとビー ムサイズが伝播距離に比例して広がるため，ピーク強度 は伝播距離の自乗に反比例して低下する。宇宙用途で重 量が制限される場合, レーザー射出系の光学系サイズも 制限されるため, 伝送用に巨大な出力ミラーを用いるこ とは困難である。また，大型のミラーは製造の過程で波 面精度の維持が難しくなる. 以上のような理由から，ガ ウスビームによるエネルギー伝送では，ミラーサイズで 伝播距離が制限される。一方, ベッセルビームには, 強 
度分布を変えずに長距離を伝播する, 光軸上の光強度が ガウスビームよりも高いという2つの利点がある5,6). そこ で, 我々は, ガウスビームからベッセルビームへのモー ド変換を考えた. ベッセルビームは, 円環状のビームか らアキシコン等を利用して発生可能であることが知られ ている. ベッセルビームに関しては, レーザー加速, 加 工等に関する多くの研究が現在進行中である.

本研究は, MW以上の大出力ビームを高効率で長距離伝 送することを目指している。ここでは，多数のビームを 円環状に並べ位相結合し伝播させたベッセルビームの発 生方法について検討を行った。具体的には, 発生させた ベッセルビームの光強度分布, エネルギー集中度等に関 して実験, 計算機解析を用いて研究を行った。

\section{2. ベッセルビームの発生理論}

ベッセルビームは非回折ビームの一種である。非回折 ビームとは，伝播により強度分布が変化しないという仮 定を基にヘルムホルツ方程式により導かれる波動方程式 から得られる1つのビームの解である7). 完全な非回折 ビームは無限のエネルギーを運ぶので実際には存在しな い.しかし, 有限なエネルギーを持つ有限サイズの非回 折ビームの発生は実現可能である. ベッセルビームの発 生方法にはアキシコン, 非球面ミラーなど, いくつかの 方法がある．Durninらは，円環状の細いビームをスリット から作り出し, それをレンズで有限サイズの平面波にし て重ね合わせべッセルビームを作り出していた 5,8,9).レン ズより後方の平面波が重なりあう領域ではこれらが干渉 して擬似的なべッセルビームとなる。この擬似ベッセル ビームの生成は回折も影響するが，基本的に干渉による ものである. 今回, このDurninの方法によるベッセルビー ムの発生方法と同様の方法を用いる. Fig. 1を用いてベッ セルビーム発生に関して説明を行う。装置の構成は, 円 環のスリットとレンズであるが，ここではレンズ集光で の像が遠視野像に等しいことを用いてレンズを省略す る。この方法はレンズを置く位置は異なるが, Durninの方 法と類似している.

まず，円環状のスリットの左からスクリーンに垂直に レーザービーム (平面波)が入射される，スリット後方を伝 播する光は, 円環の幅 $\Delta に よ る$ 回折で $\theta=1.22 \lambda / \Delta$ の回折角 を持つこととなる．上下の円環から伝播する光は， $\theta$ が小 さいとして，スクリーンから次式

$$
L=\frac{d}{2 \tan \theta} \cong \frac{d}{2 \theta}=\frac{d \Delta}{1.22 \cdot 2 \lambda}
$$

で示される距離 Lだけ離れた位置から重なる，その重なっ た遠視野領域で干渉が生じ，有限サイズのベッセルビー ムが発生する. 円環ビームの直径を $d$ とすると次式

$$
\begin{aligned}
& \Delta=\frac{1.22 \lambda L}{(d / 2)} \\
& \theta=\frac{d}{2 L}
\end{aligned}
$$

でビームの幅 $\Delta$ 得られる。ただ，回折角を $\theta$, ベッセ

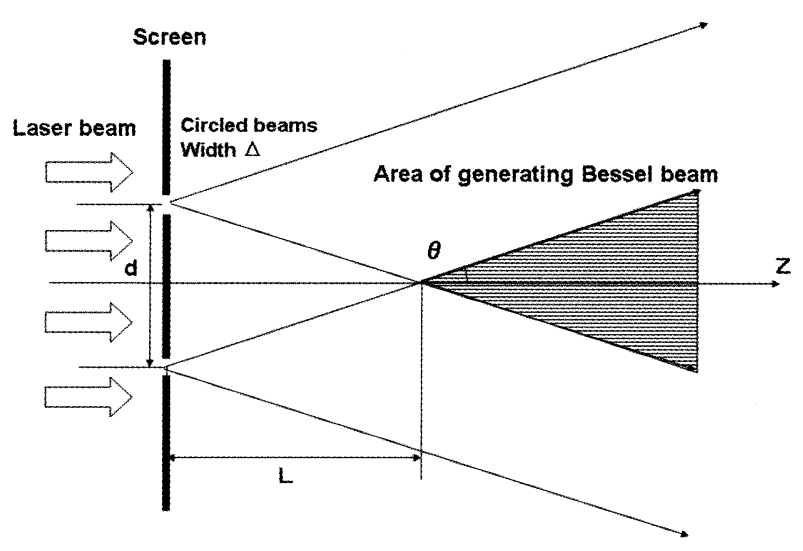

Fig. 1 Scematic diagram for generation a Bessel beam.

ルビーム発生領域までの距離を $L, \lambda$ はレーザーの波長で あり，単色であるとする。このとき，ベッセルビームの 中央ピークの半值全幅は次式

$$
D=\frac{0.76 \lambda}{\theta}
$$

で計算される. 例として, ベッセルビームを発生させた い距離 $L$ を $100 \mathrm{~m}$ としたときのビーム幅, 交差角, ベッセ ルビームの中央ピークの半值全幅を計算してみる. $d$ を 3 $\mathrm{cm}$ とし, $\lambda$ を $1 \mu \mathrm{m}$ とすると, 幅 $\Delta$ は $0.81 \mathrm{~cm}$, 交差角 $\theta$ は 0.15 $\mathrm{mrad}, 0$ 次直径は $0.51 \mathrm{~cm}$ となる。

空間に $x, y, z$ 軸を取り, $k$ ベクトルの向きを極角 $\theta$ と方

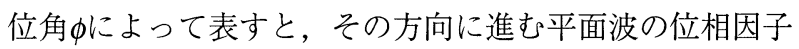
の空間依存性は次式

$$
\exp [i \alpha(x \cos \phi+y \sin \phi)+i \beta z]
$$

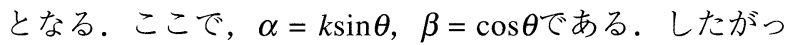
て, $k$ と暗同じで饾一様に分布した平面波の重ねあわせ により発生する電場振幅 $E$ は次式

$$
\begin{aligned}
E(x, y, z) & =E_{0} \exp (i \beta z) \int_{0}^{2 \pi} \exp [i \alpha(x \cos \phi+y \sin \phi) d \phi] \\
& =E(x, y, z) \propto \exp (i \beta z) J_{0}(\alpha r)
\end{aligned}
$$

で表される9).ここで， $J_{0}$ は第一種0次ベッセル関数，rは $z$ 軸からの距離である. 本論文の方法では, ベッセルビー ムは主に円形開口から直進する平面波の重ね合わせによ り発生するが, 円形開口と円形板による遮光が行われる 場合, ポアソンの輝点が発生する10). ポアソンの輝点に ついて, ハビネの原理により円形遮光板による振幅分布 を $U^{\prime}(Q)$, 円形開口による振幅分布を $U(Q)$, 全開の場合 を $U_{0}(Q)$ とすれば,

$$
U^{\prime}(Q)=U(Q)-U_{0}(Q)
$$

となる。軸上の強度 $I^{\prime}(Q)$ は $I^{\prime}(Q)=\left|U_{0}(Q)\right|^{2}$ となり, 遮 光板がある場合の中心強度は全開の場合と同じとなる. このポアソン輝点は, 円形開口における散乱光の $\pi$ 位相シ フトによる擬似的なベッセルビームの発生であることが 知られている11). ただし, 開口からの距離を $z_{m}, a$ を開口 のサイズとすると， $a^{2} / z_{m}$ が大きい場合は成立しない。こ のように実際には, ベッセルビームは円形開口からの散 


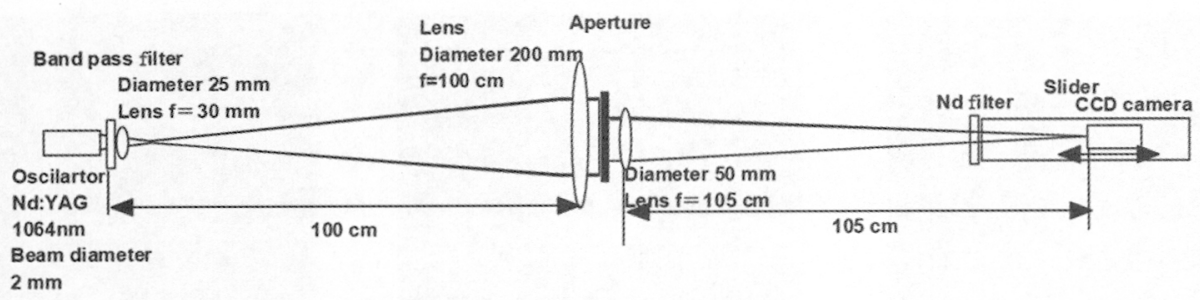

Fig. 2 Experimental setup.

乱光と直進光との重ね合わせにより発生するが，遠視野 領域での軸中心の強度分布において, 開口の散乱光によ り発生する強度成分は直進光により発生する強度成分に 対して十分低いと考えられるので，この散乱光による強 度分布はここでは考慮しない。

\section{3. 実験方法}

実験配置図をFig. 2に示す，円環状配置のマルチビーム を模擬的に作り出すため，Fig. 3に示すステンレス製金属 のアパーチャーを試作した，比較のため，3種類のアパー チャーを準備した。それぞれの厚みは $3 \mathrm{~mm} ゙$ ありり, 12 ビーム，24ビームを円環状にならべたものと完全なリン グ型の3種類のアパーチャーを試作した。リング状のア パーチャーは，直径 $100 \mu \mathrm{m}$ の針金を十字にして貼り付け 固定した。1個の出力ビームの直径は $3 \mathrm{~mm}$ であった。この アパーチャーの試作の際，アパーチャーの片面に縁を鋭 いエッジ状に製作し，ビーム回折の位置をそろえようと した、レーザー発振器には，Nd:YAGレーザー(波長1064 $\mathrm{nm})$ を用いた。レンズ系でビームの直径を $5 \mathrm{~cm}$ ま゙拡大 し，コリメートした後，アパーチャーに入射した。衤の 際，ビームは2つのレンズで平行化されている。辛れぞれ

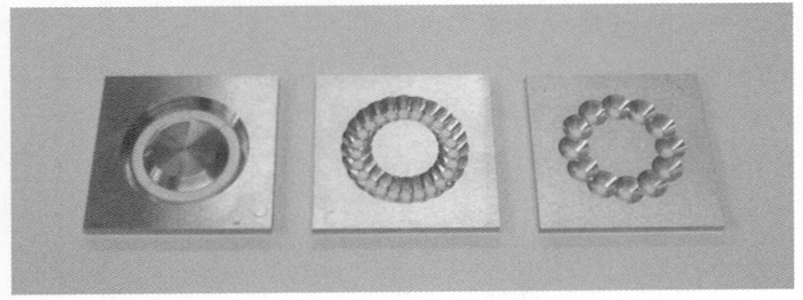

Fig. 3 Apertures for generating ringed beam(left), annularly arranged 24 beams (center)and 12 beams (right). Outermost and innermost diameters of three apertures are $30 \mathrm{~mm}$ and $24 \mathrm{~mm}$, respectively, and the diameter of every hole is $3 \mathrm{~mm}$.
の1本のビーム出力は, 矩形強度分布を持つ円形ビームと なっている.アパーチャーの透過光は焦点距離 $105 \mathrm{~cm} の レ$ ンズをとおり，遠視野像が集光位置に現れる。CCDカメ ラをビームの伝播方向に移動して遠近視野像と遠視野像 を観測した。その間，バンドパスフィルター, NDフィル ターによりレーザー強度の減衰を行った。

レーザー光のエンサークルドエネルギーの評価を行っ た。発生したベッセルビームのエンサークルドエネル ギーは，集光位置にピンホールを抻入し，その開口径を 変えながら透過光のパワーをPINダイオードで計測し，強 度比を算出した。CCDカメラを用いて，強度分布を観察 しながらピンホールをビームの中心部に配置した．CCD カメラは，ビームの伝播方向にスライド可能であった.

\section{4. 実験結果}

ビームプロファイル観測結果をFig. 4に示す.Fig. 4は， レンズ集光位置から手前に $10 \mathrm{~cm}, 6 \mathrm{~cm}, 0 \mathrm{~cm}$ の位置での CCDによる集光位置での強度分布である。これらは 4.8 $\mathrm{mm} \times 3.6 \mathrm{~mm}$ の領域を示している。これは，24ビームの場 合の結果であり，遠近視野領域で24個のビームが隣接す るビーム間で干渉を生じていることがわかる。この円環 状配置のビームは内径と外直径では内側が小さいため, 外側にも回折を起こすがそれよりも内側に向かって強く 回折が生ずる. $6 \mathrm{~cm}$ 手前の位置ではすでにビームの重なり により中心部に輝点が観測されている。これは, 前述し たポアソン輝点と考えられる.

Fig. 5は，レンズ焦点位置，遠視野でのビームプロファ イルである。円環の場合と24個の場合の差はほとんど見 られない。しかし，12個ビームの場合では，中心の周り に強度の高い点が多数存在することになり完全な有限サ イズのベッセルビームの発生が行われなかった. Fig. 6 は，24ビームの場合のビーム伝播計算の結果である。実 験結果との比較のため，ビーム伝播解析コード (LOCCO)
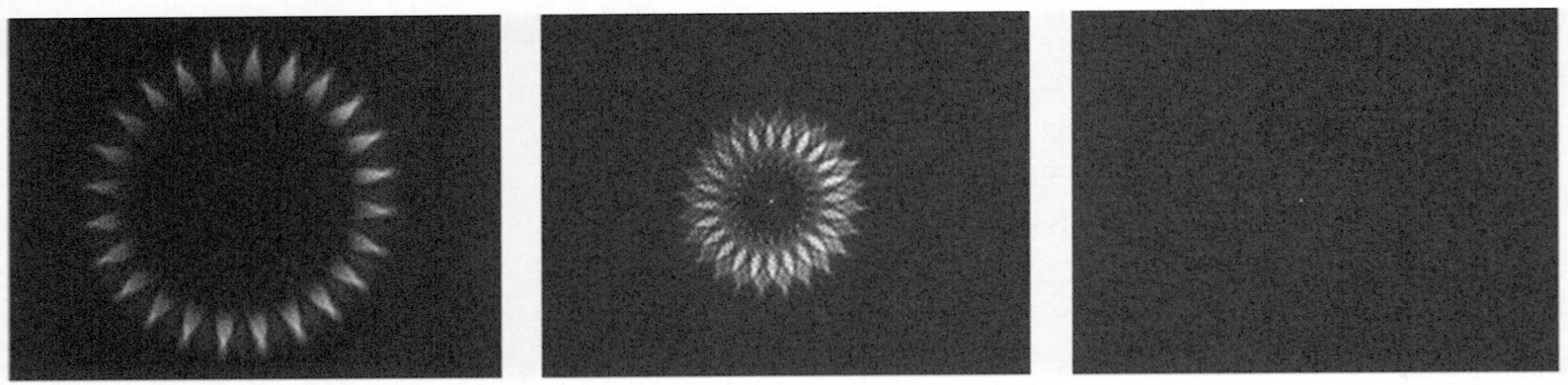

Fig. 4 Intensity distribution of annularly arranged 24 beam by $10 \mathrm{~cm}$ (left), $6 \mathrm{~cm}$ (center), and $0 \mathrm{~cm}$ (right) apart from beam west toward the aperture. 

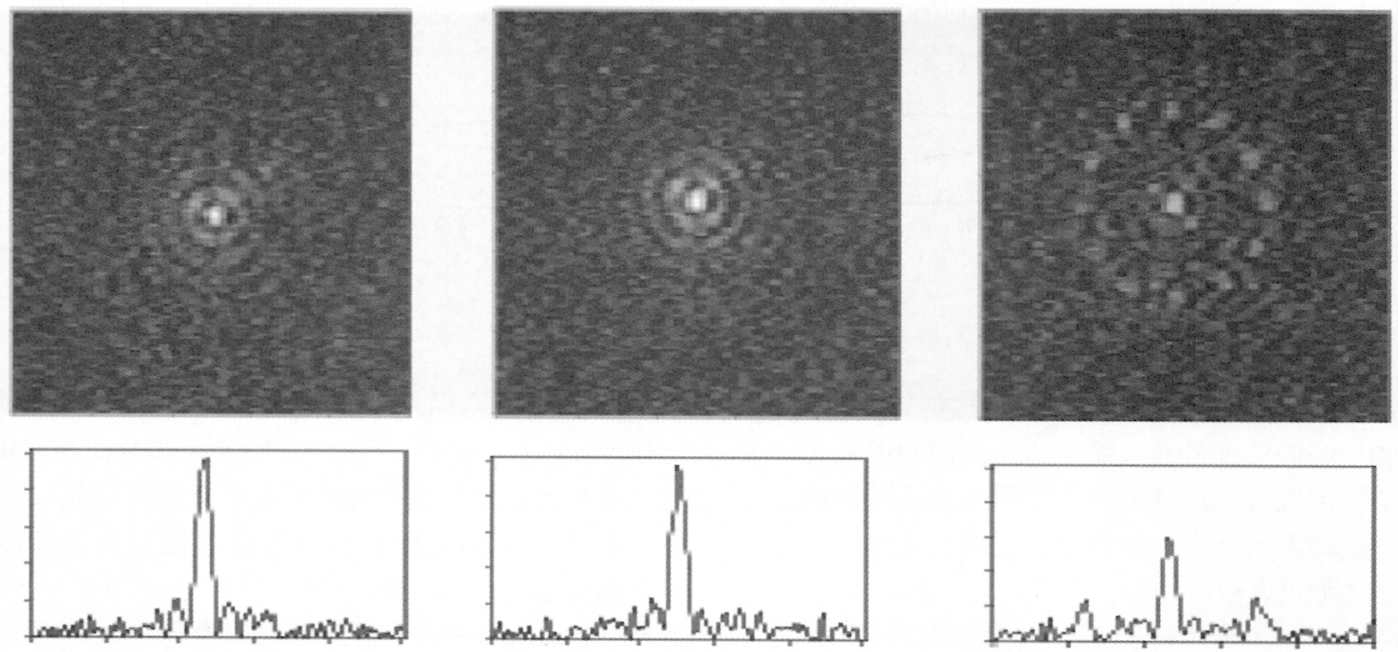

Fig. 5 Far-field image of beam profile of the ringed beam (Left), annularly arranged 24 beams(center) and12 beams (right) at the beam waist. The diameter of each center peak was $60 \mu \mathrm{m}$ (FWHM).
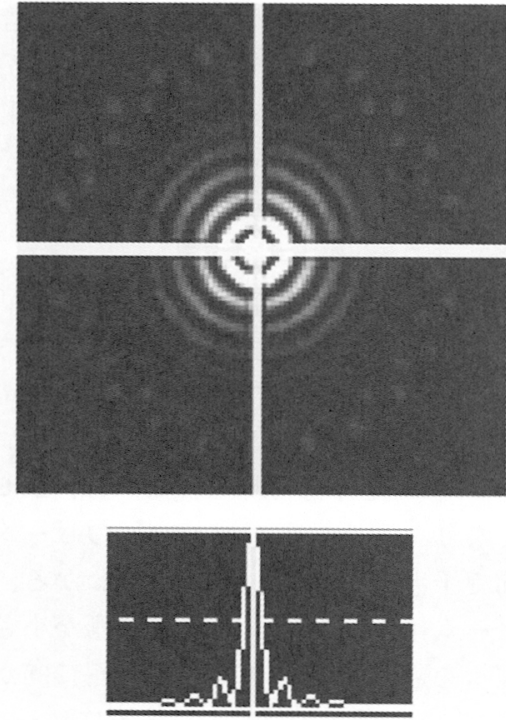

Fig. 6 Calculated far-field image and beam profile for annularly arranged 24 beams at the beam waist. The diameters of the center peak was $60 \mu \mathrm{m}$ (FWHM).

を用いて同じ光学配置を用いてエネルギー集中度の計算 を行った ${ }^{12)}$ 。このコードは, 実際の光学装置の位置を入 カし, フーリエ変換により2次元で回折を含む近軸近似で のビーム伝播の解析を行うことが可能である。ただし， 計算では開口部の散乱による位相シフトの効果は考慮し ていない。この計算結果はFig. 5の実験結果とほぼ一致し ている.

Fig. 7にベッセルビームのエンサークルドエネルギーの 評価を行った結果を示す。エンサークルドエネルギーと は，光軸を中心にした円内に含まれる光エネルギーで， エネルギーの集中度を評価する方法である．Fig. 7の横軸 は, 円の半径, 縦軸はアパーチャーを透過したエネル ギーに対するエンサークルドエネルギーの割合である。 集光位置にピンホールを配置しない場合を1とした。それ ぞれ，3つのアパーチャーの場合の評価を行った。リング 型ビーム，24ビーム，12ビームの場合, 中心位置から直

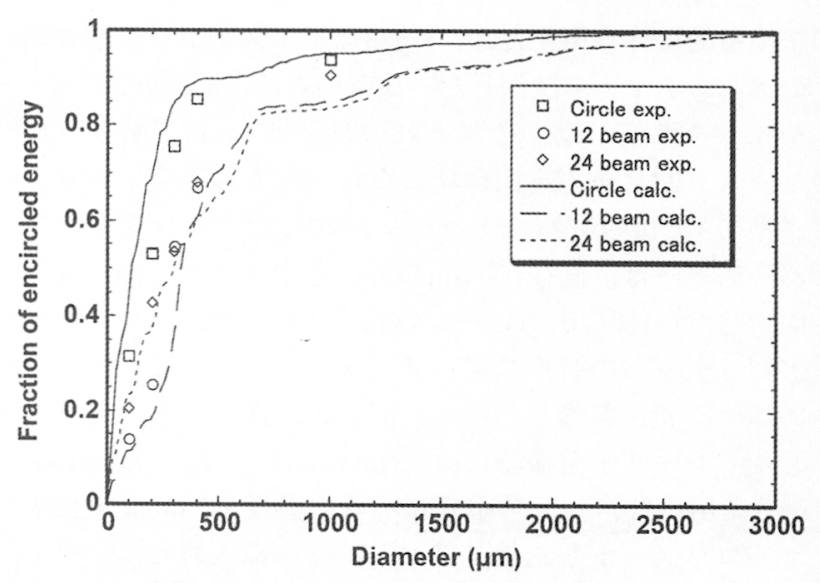

Fig. 7 Observed and calculated encircled energy. Dots are measured results and lines are calculated results.

径500 $\mu \mathrm{m}$ ではそれぞれ90，70，70％のエネルギーの集中 が観測された。実験結果との比較のため, 同様に先ほど 述ベたビーム伝播解析コードを用いて同じ光学配置を用 いてエネルギー集中度の計算を行った。24ビームの場合 のみビーム間の相対位相差をパラメータとし, ベッセル ビーム発生の計算機解析を行った。ビーム間の相対位相

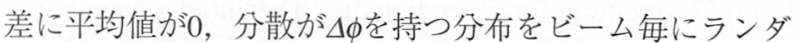
ムに与えて 24 ビームから発生する擬似ベッセルビームの 強度分布と断面の強度プロファイルを計算した。その結 果, エンサークルエネルギーの実験と計算結果は非常に 良い一致を得た。その結果をFig. 8 (a)，（b)に示す。相対 位相差 $\Delta \phi か ゙ 0.5 \pi$ 以上の場合ベッセルビームの発生が困難 となることがわかった。

\section{5. 議論と考察}

マルチレーザービームから発生した大出力のベッセル ビームの伝送を模擬した実験を行った。 ビームを円環状 に密に配置し，そのビームの波面，波面乱れの少ない レーザービームの伝送方向をそろえることでベッセル ビームが発生することが実験的に確認された。この研究 

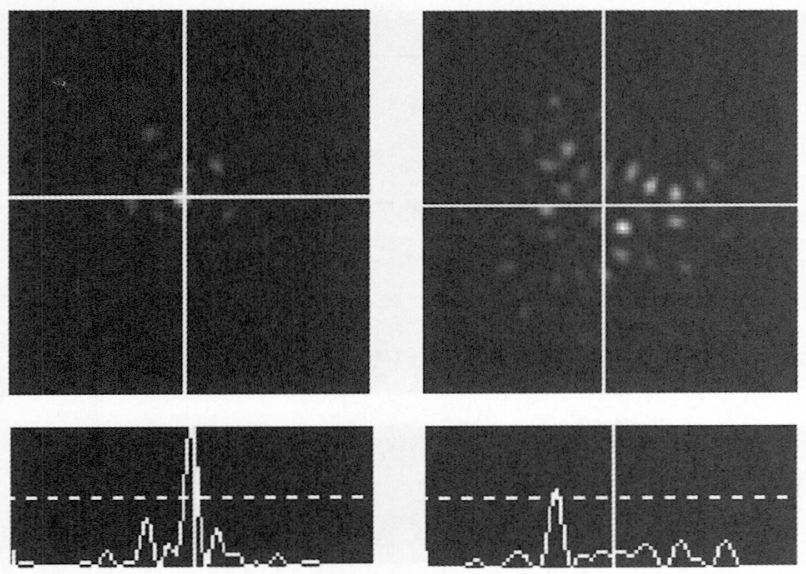

(a)

(b)

Fig. 8 Calculated far-field images and the beam profile along the horizontal line for annularly arranged 24 beams with a relative phase variance $\Delta \phi$ of $\pi$ (left), $2 \pi$ (right).

は，将来のMW級のエネルギー伝送用高平均出力レーザー システムを構築する上で意義深い。エネルギー集中度の 実験結果と計算結果はその誤差が5\%以内で，良い一致を 見せた。計算よりもエネルギー集中度が低い理由は，開 口の製作誤差によるものと考えている。しかし，実際の システムでは，発生，伝送，受信が必要であり，それぞ れで解決すべき問題がある。発生に関して，各ビームの 位置精度, 向き, 相対位相差, そ扎らの安定性, また, 個々のビームの強度分布がガウス分布，トップハット分 布等に限られた場合には, ベッセルビームへ効率良く変 換できない可能性がある，大口径ビームでは，ビーム品 質が問題となるであろう。各ビームの波面精度がベッセ ルビームの発生の可否を決めると予想される。システム の都合上, ビームの光学配置の問題がある.

伝送に関して，宇宙空間では大きなビーム伝送効率の 低下はないと思われる。しかし，地上では大気擾乱など の問題がある。また，連続波では問題にならないが，パ ルスレーザーなどの場合はレーザー強度に依存した熱ブ ルーミング，非線形効果による伝送効率の低下が考えら れる。それらはビームの位相を乱す方向に働くと考えら
れる，計算上は，ベッセルビームは，多少の波面の乱れ に対して鈍感，すなわち，中心のピーク強度を維持する ことができることが明らかとなっている。今後，この ビームでの地上での伝送実験により伝送特性を明らかに する必要がある。

光電変換素子にベッセルビームを入力する場合, ビー ム全体のレーザー強度を均一化するホモジナイザーやマ ルチモードファイバへの入力により強度を均一後に光電 変換素子に入力することでエネルギー利用効率の改善が 可能であることが考えられる.

\section{6. 結 論}

円環状に配置したマルチビームの伝播により，ベッセ ルビームが発生することを実験的に示した。 ビーム数が 多くなり，ビーム間隔が密になることで，円環状ビーム と変わらないエネルギー集中度が得られることが実験 的, 計算機解析の結果, 明らかになった。エンサークル ドエネルギーは，実験結果と計算結果の間に良い一致が 見られた。

\section{参考文献}

1) S. Redmond, S. Mcnaught, J. Zamel, L.Iwaki, S. Bammert, R. Simpson, S. B. Weiss, J. Szot, B. Fregal, T. Lee, et. al.: Tech. digest of CLEO/QELS (2007) CTuHH5.

2) 白川晃, 植田憲一：レーザー研究 33 (2005) 254.

3) 藤田 辰人, 森 雅裕, 久田安正, 福室 康行, 木皿且人, 瀬在 俊浩, 吉田裕之, 鈴木 拓明：第27回宇宙エネルギーシ ンポジウム(日本宇宙航空研究開発機構，2008).

4）河島信樹, 武田和也, 矢部恭一, 金洪人, 広瀬 虎瑠：第 26 回宇宙エネルギーシンポジウム論文集（日本宇宙航空研究 開発機構, 2007) p.72.

5) J. Durnin: J. Opt. Soc. Am. A 4 (1987) 651.

6）有賀 規, 國森 裕生：情報通信研究季報 50 （2004） 105.

7) S. M. Barnett and L. Allen: Opt. Commun. 110 (1994) 670.

8) J. Durnin, J. J. Miceli, Jr., and J. H. Eberly: Phys. Rev. Lett. 58 (1987) 1499.

9）森村 正直：極限光技術（オプトロニクス社，東京）p. 35 .

10) 辻内 順平 : 光学概論 II (朝倉書店, 東京) p. 100 .

11) S. Wang, Q. Lin, and X. Lu: On the Nature of Diffraction and New Beam Lasers (Hangzhou University Press, China) p.65.

12) W. W. Shimons, J. T. Hunt, and W. E. Warren: IEE. J. Q. E. QE-17 (1981) 1727. 